\title{
Flexibility in New Zealand Workplaces: a Study of Northern Employers
}

\author{
Rose Ryan*
}

This article reports on the results of a questionnaire survey undertaken in AugustSeptember 1991 on the employment practices of members of the Auckland Employers' Association. It looks at the ways in which flexibility in employment practices differs amongst Northern employers, and suggests that these vary in different sectors of the economy and in firms of different sizes, with the predominant tendency being towards the adoption of short-term rather than long-term adjustment strategies.

\section{Introduction}

The debate on the need for greater flexibility in the labour market in New Zealand has led many commentators to examine how flexibility is exhibited, both economy-wide and at the level of the workplace. More recently, as a result of deregulation in the economy, increased competitive pressures and the influence of the international debate on labour market flexibility, greater attention has been paid to the ways in which firms achieve flexibility of the labour process at the level of the workplace. This includes wage aspects (including the ways in which wages are used to motivate employees to higher levels of productivity), non-wage labour costs (including health and welfare measures) and other non-wage issues (such as employment structures and alternative forms of work organisation). The debate on non-wage forms of flexibility has been relatively recent in New Zealand. Over the past few years, changes to bargaining arrangements in some large firms, such as Nissan, Fortex, and Fisher and Paykel, have resulted in well-publicised changes to work organisation which have been heralded as being part of a new era. (See for example, Owen, 1990; Williams, Owen and Emerson, 1991; Taylor, 1991; Birch, 1991) Others have argued that the changes that have been put in place are more limited. The recent passage of the Employment Contracts Act has put greater pressure on employers to engage in labour planning, although the extent to which employers are responding to this challenge is as yet unknown.

This article is based on research undertaken while the author was a Masters student at the University of Auckland. Particular thanks for their support and enthusiasm during the course of the research are owed to Mr Peter Carroll, General Manager of the Auckland Employers' Association, and Dr Nigel Haworth who supervised the research. I would also like to thank anonymous Journal referees for their constructive comments. 
Despite the anecdotal evidence that is used to both support and deny evidence of industrial relations change, little empirical research, with the notable exception of McAndrew's studies of Southern employers (McAndrew, 1989; McAndrew and Hursthouse, 1991) has been done in New Zealand to measure the extent of change, or to gauge exactly what it is that employers want. The neglect of employer concerns in industrial relations research in New Zealand has been noted previously (Brosnan, Walsh and Rowe, 1985) although little has been done to rectify the problem since this comment was made. Neither is New Zealand alone in the paucity of research that is carried out on employer approaches to industrial relations. It has only been in the $1980 \mathrm{~s}$, as the balance of bargaining advantage has been tipped back in favour of employers by economic recession, that studies on employer strategies and employment practices have become more common. These studies have involved a fusion of perspectives from both organisational theory and industrial relations. In general, two approaches have been taken. The first of these focuses on management style, and the ways in which this affects different industrial relations outcomes (Poole et al., 1982; Purcell and Sisson, 1983; Horstman, 1988; Baglioni, 1990). A second body of work has considered the impact of organisational structure and size on industrial relations (Marginson, 1984; Marginson et al., 1988; Batstone, 1988). This latter body of work has been particularly important given the speed of organisational change in the 1980s, most notably in relation to flatter management structures, devolution of managerial decisionmaking to decentralised business units or profit centres, and changing patterns of ownership.

This paper aims partially to rectify the traditional imbalance in New Zealand industrial relations research by reporting the results of a survey of members of the Auckland Employers' Association on aspects of non-wage flexibility. Prior to setting out the results, it outlines the different types of flexibility delineated within the literature, conclusions that have been reached from international studies, and indicators of the different types of flexibility in the New Zealand context. The paper concludes by suggesting that Northern employers vary by size and industry in the types and level of flexibility that they seek, and that there is a general tendency on the part of employers towards using short-term rather than long-term strategies.

\section{Workplace flexibility}

The concept of labour market flexibility may be viewed along two dimensions. The first of these is the level at which indicators of flexibility are measured. Most attention has been paid in this respect to the macro-economic level, with studies looking at aggregate wage movements and relativities, levels of employment and unemployment, productivity and labour mobility (OECD, 1986a; OECD, 1987; Economic Monitoring Group, 1987). More recently, greater attention has been paid to the micro-level, and the ways in which flexibility in labour usage is exhibited at the workplace (Atkinson and Meager, 1986; OECD, 1989). This latter approach has assumed greater prominence firstly because of the need for firms to adjust to changes in product and factor markets in order to meet increased competition, and secondly because existing arrangements in relation to collective bargaining and job protection have been argued to have reduced the ability of firms to adapt to major structural change (OECD, 1986a). This focus on the workplace also indicates the second dimension along which the concept of labour market flexibility may be measured - the different types of flexibility that are demonstrated or exhibited 
by firms. Over the past decade, a number of typologies have been developed, some of which bear little resemblance to each other in their detail. (See for example OECD, 1986b; Atkinson and Meager, 1986; Boyer, 1988; Sarfati and Kobrin, 1988; Brunhes, 1989.) In general, however, three types of flexibility are recognised. The first of these relates to quantitative flexibility, that is, the extent to which employers are able to adjust the quantity of labour required in order to meet fluctuations in demand as they occur. This may be done either internally within the firm by adjustment of the hours worked by employees (for example, by the employment of staff outside normal hours of work) or by resorting to the external labour market (for example, by taking on temporary workers or by contracting work out).

The second type of flexibility is qualitative - that is, the way in which firms utilise their workforce. The hallmark of Taylorist forms of work organisation which became common throughout the twentieth century was the breaking down of tasks into component jobs, with a high degree of job and skill specialisation. This resulted in a wide range of co-ordination and control problems for management, and a loss in quality of working life for employees. In addition a wide variety of product and factor market considerations have contributed to pressures for change. Consequently, there has been a growing emphasis in post-Fordist forms of work organisation on the reintegration of job tasks, multi-skilling, training, and a breakdown in traditional demarcations. The sorts of changes that have been implemented have been widely discussed in the literature (OECD, 1986a; OECD, 1987; Boyer, 1988; Bamber, 1990). They suggest that the introduction of qualitative flexibility strategies may be particularly important in relation to specific types of change. The introduction of new technology, for example, may require the labour force to acquire an expanded range of skills, particularly where the cost of new machinery, shortened product life cycles, and demand for custom made products require high capacity utilisation and shorter production runs.

The third type of flexibility that is distinguished in the literature is that of labour costs. Flexibility in this area may focus on one of two aspects. The first is related to payment systems and commonly involves changes to the basis on which these operate, for example through a move to performance or profit-based systems. The second type of labour cost flexibility that may be sought is where employers seek to directly reduce wages and conditions. Wage flexibility is usually not sought on its own, but is used to support and reinforce practices for qualitative or quantitative flexibility. Thus, for example, payment systems based on skill, rather than a rate for the job, may be implemented to support new workplace-based training systems, or reductions in penal rates may be sought where a cheaper alternative source of labour is readily available.

The introduction of the concept of labour market flexibility has led to debate on a variety of conceptual and empirical issues. In particular, in the United Kingdom, empirical evidence supporting the usefulness of the concept of flexibility as a descriptor of labour market change in the 1980s has been somewhat inconclusive. A key study by the influential Institute of Manpower Studies (Atkinson and Meager, 1986), conducted on the basis of a limited sample, suggested that the search for labour market flexibility, and in particular the separation of the workforce into a "core" and a "periphery" represented a fundamentally new strategy by employers to adjust to changing economic circumstances. This proposition has been challenged (Pollert, 1987; Pollert, 1988 ) on the basis that segmented labour market theorists have posited the existence of a dual labour market for some time. In this respect it may be noted that the concept of flexibility (and in particular qualitative flexibility) is operationally similar in many ways to those which 


\section{Rose Ryan}

Doeringer and Piore (1971) saw as being characteristic of the operation of internal labour markets. Pollert also uses evidence from studies of workplace industrial relations (Millward and Stevens, 1986; Marginson et al., 1988) to suggest that the increase in "atypical" forms of employment (such as temporary and contracting work) is explicable largely with reference to sectoral change in the economy, and in particular the increased importance of the service sector. Further evidence from the UK has largely supported this hypothesis, with one study (Hakim, 1990) finding that increased use of "peripheral" workers was due to their increased use in traditional areas of their employment, but that they were not being employed in other sectors to any significant degree.

The New Zealand debate on flexibility has focused on the fact that we need "more", while making little distinction about the sort of flexibility that is required, or the levels of flexibility that are being aimed for. The international experience, however, suggests that successful adjustment strategies involve a more sophisticated approach to the problem. In particular, there appear to be major differences in approach between those firms and enterprises which adopt strategies for quantitative flexibility, and those which place greater emphasis on qualitative flexibility. Three main conclusions may be reached from the studies that have been carried out across a range of countries.

The first of these is that the national context (and in particular the regulations and legislation affecting labour market functioning) has a major impact on the type of flexibility that is made use of. Thus, for example, Brunhes (1989) has suggested that the tendency for Sweden to rely largely on qualitative forms of flexibility is a result of the high degree of social consensus operating within the country, and of strict legislative restrictions on the use of forms of labour that are associated with a high degree of quantitative flexibility. In contrast, in France, recent easing of legislative restrictions on the use of temporary workers and fixed-term contracts has led to a burgeoning in this type of employment. Similarly, in Belgium, the emphasis has been on working time, with a series of experiments designed to increase employment through the use of more flexible working hours. Rules relating to collective bargaining and worker participation may also have an effect on the type of flexibility that is adopted. The implementation of strategies for qualitative flexibility will commonly require the active cooperation of the workforce, whereas quantitative flexibility may be imposed on a workforce by management without consent or participation.

A second conclusion that may be reached is that different types of flexibility may be utilised under different conditions. The introduction and use of new technology, for example, may require functional flexibility, as noted earlier. In contrast, in industries which are labour, rather than capital intensive, the existence of high levels of unemployment has put workers into competition with each other, increasing pressure on labour costs and often leading to a casualisation of the workforce. The transactions costs associated with alternative forms of adjustment strategies may also affect the types of flexibilities which are adopted (Savage, 1989). Finally, the involvement of trade unions at the workplace may also have an effect on the type of flexibility that is adopted, with some suggestion that internal, qualitative flexibility measures are more likely to be introduced through a process of collective bargaining, while external, numerical forms of flexibility are more likely to be introduced where unions refuse to bargain on flexibility issues (Baglioni, 1990) or where particular management styles are adopted (Horstman, 1988). 
Finally, there is some suggestion that different types of flexibility may lead to differing degrees of long and short-term adjustment. A high degree of qualitative flexibility appears to be associated with a considerable degree of employment security, thus guaranteeing employers a return on their training investment and providing workers with an incentive to learn new skills. Such is the case in Japan, where the system of life-time employment, while only applying to a small percentage of the workforce, encourages those workers to be highly committed to the firms in which they are employed. Similar developments occurred with concession bargaining in the United States, where assurances on employment security were given in a number of firms in exchange for union guarantees that traditional job demarcations would be broken down. In contrast, where firms make considerable use of quantitative flexibility, there is little incentive for them to invest in training or development. This may, in some cases, reduce their ability to be more adaptable in the long term. In this regard, it is notable that a number of studies have pointed to the necessity of long-term flexibility, and the importance of skills and training in achieving productive efficiency. The OECD (1987) for example, has commented that patterns of production are changing in ways which place a higher premium on flexibility in the deployment of labour within the firm, and that this aspect of labour market functioning must be improved if labour market institutions are to contribute to sustained employment growth. Similarly, Meulders and Wilkin (1987) have suggested that we must look critically at the issue of short-term versus long-term flexibility in order to consider whether rapid adaptation encourages the long-term survival of an organisation or simply puts a hidden mortgage on its future.

\section{Indicators of flexibility}

The above discussion suggests that the adoption of either quantitative or qualitative forms of flexibility is a choice which must be made by individual employers in light of the environment in which they are operating. This environment includes regulatory and legislative constraints, the general state of the economy, and the specific conditions applying in product and factor markets. What are the ways then in which different types of flexibility are indicated?

As noted earlier the concept of quantitative flexibility involves the ability of employers to adjust the quantity of labour inputs to changes in demand for their goods and services. Internally, this may be achieved through flexible working time arrangements. The most commonly used of these types of arrangements in the New Zealand context include overtime and shift work, flexi- and glide-time arrangements, and more recently, an extended span of "ordinary hours" within which work may be scheduled. A range of other means of achieving internal flexibility (such as rostered days off, short-time working, and compulsory taking of annual leave) may be found in other countries, but are not commonly used in New Zealand.

In addition to being able to adjust their quantity of labour input internally, employers may also make the required adjustment through recourse to the external labour market. This may be achieved through greater use of temporary or casual workers, part-time workers whose hours may be increased or decreased as needed, and use of subcontractors or franchising arrangements.

Qualitative flexibility, on the other hand involves both the capacity of workers to undertake a range of tasks, and the capacity of the employer to move workers from one task to 
another in order to address imbalances in demand, or "bottlenecks" in production. Qualitative flexibility can be achieved only by addressing two issues in tandem - employers must be prepared to train workers in a wider range of skills, while unions must allow the blurring of traditional demarcations between craft groups, and between craft and process work. This may be achieved through a reduction in the number of occupational classifications, and through active consideration of work organisation and job design issues, for example by introducing job enlargement and job rotation schemes.

Having set out indicators of the different types of flexibility that may be achieved by employers in their labour practices, we now turn to look at the types of flexibilities that are sought by New Zealand employers. Data on this was obtained through a survey of members of the Auckland Employers' Association in 1991. The methodology and results from the survey are set out below.

\section{Survey design}

The questionnaire was developed in consultation with the Auckland Employers' Association. It consisted of 30 questions split into four sections, which generally required fixed alternative or short answer responses, although six open questions were included to get some indication of the motivation for employer choices in determining their employment practices. All members of the association received a copy of the questionnaire in the association's general mail-out in mid-August 1991. They were given until the end of September to reply to the questionnaire, using a pre-paid envelope addressed to the Department of Management Studies and Labour Relations at the University of Auckland. In all, 1,335 questionnaires were returned, generating 1,321 usable responses. This represents a response rate of $34.7 \%$ of association members.

\section{The respondents}

The typical respondent was a Chief Executive or Managing Director of a stand-alone company employing 10-49 staff, and based in Auckland. The industry breakdown of respondents can be seen in Table 1 .

As the Auckland Employers' Association does not keep statistics on its membership by size or industry, it was not possible to ascertain whether the respondents to the survey were representative of this membership. Consequently, the respondent profile was compared to that established by the Department of Statistics from its Business Directory in order to assess its representativeness (Department of Statistics, 1990). From this comparison, it must be noted that while the respondents are inclusive of all groups across the economy, it cannot be claimed that the survey has achieved this proportionately for all groups. In particular, there is an overrepresentation of employers from the Manufacturing sector, and a slight under-representation of employers from Service Sector groupings. In addition, larger employers were over-represented in relation to their proportion in the population. Thus, it must be accepted that the results may include both sampling bias (if the Employers' Association mailing list is not representative of the 
industry and size distribution of Northern firms generally) and non-response bias (if some classes of employer responded to the questionnaire in higher proportions than others). Having made this caveat, the size of the survey and the fact that all categories of firms (with the exception of Mining and Quarrying which has been included with Agriculture as a Primary sector grouping in analyses) are well represented among the respondents, gives some considerable measure of confidence in the results.

Table 1: Distribution of respondents by industry

\begin{tabular}{lrr} 
Industry & Frequency & Percentage \\
\hline Agriculture, Hunting, Forestry, and Fishing & 52 & 3.9 \\
Mining and Quarrying & 6 & 0.5 \\
Manufacturing & 440 & 33.3 \\
Electricity, Gas and Water & 22 & 1.7 \\
Construction & 99 & 7.5 \\
Wholesale and Retail Trade & 260 & 19.7 \\
Restaurants and Hotels & 42 & 3.2 \\
Transport and Storage & 75 & 5.7 \\
Communications & 43 & 3.3 \\
Business and Financial Services & 72 & 5.5 \\
Community, Social and Personal Services & 147 & 11.1 \\
Central or Local Government & 20 & 3.3 \\
Unspecified & 43 & 3.3
\end{tabular}

\section{Results} flexibility.

The results are analysed according to indicators of both quantitative and qualitative

\section{Quantitative flexibility}

In relation to external quantitative flexibility, the questionnaire asked a number of questions about the employment structure of the respondent firms. These focused on current and anticipated employment of full-time, part-time and temporary employees, and use of contractors or homeworkers. In relation to the internal aspects of quantitative flexibility, respondents were asked about their working time arrangements, and whether they would be seeking to change these in the future.

The type of contract that is offered to employees may vary along several dimensions such as the number of hours that are offered to employees (that is, whether they are full-time or parttime), the permanence of the contract (that is whether it is permanent or temporary), and whether 
the employee is engaged under a contract of service or a contract for services (employee/ homeworker or contractor).

From the responses to the questionnaire, it can be seen that the vast majority of employers employ full-time staff. Use of other than full-time staff is also common among Northern employers, however, as the table below illustrates.

Table 2: $\quad$ Frequency of employers making use of alternative forms of employment contract

\begin{tabular}{lrc} 
Type of Employee\# & Frequency & Percentage \\
\hline Full-time* & 1,278 & 96.7 \\
Part-time* & 926 & 70.7 \\
Temporary* & 893 & 68.0 \\
Contract & 632 & 48.0 \\
Homeworkers & 116 & 8.8
\end{tabular}

\# Respondents were asked about their employment patterns at the time of the questionnaire, except in the case of temporary workers where they were asked about the number of employees who had been engaged for a limited time only in the year prior to the survey.

* $\quad$ Full-time employees were defined as those working 30 hours or more, while part-timers were defined as those working less than 30 hours. Temporary employees were defined as employees who were engaged for a limited time only.

For a small number of firms, the use of part-time and temporary workers, rather than fulltimers, appears to be standard practice. For example, $10.7 \%$ of respondents employed a larger number of part-time workers than full-time workers, and $10.0 \%$ employed more temporary workers than full-timers. In addition, where employers make use of other than full-time workers, they tend to be more likely to employ a mix of different types, with only $6.8 \%$ of employers employing only full-time workers. Table 3 sets out the variations in employment structures used by respondents in the survey.

An analysis of these structures by industry and size reveals some interesting, if not altogether surprising, patterns. While just over $67 \%$ of employers employed less than five parttime workers, those that employed large numbers of part-timers were overwhelmingly concentrated in service sector groupings, namely Restaurants and Hotels, Business and Financial Services, Central and Local Government, and Community, Social and Personal Services. The same pattern followed for use of temporary employees, where employers in the primary sector, in Construction and in Restaurants and Hotels were more likely than others to employ large numbers of temporary employees. Given the seasonal and demand-driven nature of a number of these industries, a picture is suggested whereby employers use the employment structure of 
their firms in a way which allows them to adjust to fluctuations in the patterns of demand for their goods and services.

Table 3 : Employment structure of Northern firms

\begin{tabular}{lcr} 
Employment structure & Frequency & Percentage \\
\hline Full-time workers only & 90 & 6.8 \\
Part-time only & 157 & 11.9 \\
Temporary only & 107 & 8.1 \\
Contract only & 80 & 6.7 \\
Part-time and temporary & 332 & 25.1 \\
Part-time and contract & 101 & 7.7 \\
Temporary and contract & 115 & 8.7 \\
All three & 339 & 25.7
\end{tabular}

This picture is confirmed if we consider employer preferences on the type of employee that they would prefer to hire if they were to take on additional employees and the reasons for their preferences. Just on $45 \%$ of employers stated that they would prefer to take on full-time employees, while part-time and temporary employees were preferred by $21.3 \%$ and $28.8 \%$ of employers respectively. An additional $5.1 \%$ of respondents replied that they would prefer to employ a mix of employee type, or that the type of employee selected would depend on the circumstances operating at the time. Explanations for employer preferences varied according to employee type, as is demonstrated in Table 4.

While there is some overlap in the categories that are outlined here, the data suggest that employers use part-time and temporary workers in ways which allow them to adjust to patterns of demand in their industry which may fluctuate on either a regular or an unpredictable basis. The pattern of demand applying for each business will influence the employer's decision as to whether part-timers or temporary staff are selected. Thus, part-timers will be the preferred option where demand peaks on a regular, predictable basis (such as, for example, lunch-time or weekend trading hours in retail stores) while temporary workers will be used where demand is infrequent and/or unpredictable (such as, for example, seasonal work in horticultural industries, or a one-off order for a manufacturing plant). Thus the demand patterns faced by employers in Northern firms would appear to be met at least in part through the structure of the workforce that they employ. 
Table 4 : Reasons for preference according to employee type

\begin{tabular}{|c|c|c|}
\hline Full-time & Part-time & Temporary \\
\hline $\begin{array}{l}\text { Skills needed for } \\
\text { job }(25.2 \%)\end{array}$ & $\begin{array}{l}\text { Nature of demand } \\
\text { for job }(33.8 \%)\end{array}$ & $\begin{array}{l}\text { Nature of demand } \\
\text { for job }(39.1 \%)\end{array}$ \\
\hline $\begin{array}{l}\text { Stability and } \\
\text { reliability }(18.4 \%)\end{array}$ & $\begin{array}{l}\text { More flexible } \\
(32.8 \%)\end{array}$ & $\begin{array}{l}\text { More easily disposable } \\
(22.6)\end{array}$ \\
\hline $\begin{array}{l}\text { Required by nature } \\
\text { of industry }(13.6 \%)\end{array}$ & $\begin{array}{l}\text { Required by nature } \\
\text { of industry }(11.5 \%)\end{array}$ & $\begin{array}{l}\text { Environmental } \\
\text { uncertainty }(22.3 \%)\end{array}$ \\
\hline $\begin{array}{l}\text { Commitment to } \\
\text { job/company }(11.6 \%)\end{array}$ & $\begin{array}{l}\text { Environmental } \\
\text { uncertainty }(9.7 \%)\end{array}$ & More flexible $(13.3 \%)$ \\
\hline $\begin{array}{l}\text { More flexible } \\
(7.5 \%)\end{array}$ & $\begin{array}{l}\text { More productive } \\
(4.7 \%)\end{array}$ & $\begin{array}{l}\text { Required by nature of } \\
\text { industry }(5.3 \%)\end{array}$ \\
\hline
\end{tabular}

Quantitative flexibility can also be achieved through working time arrangements applying in a firm, as indicated both by the number of hours for which a workplace is open and the working time patterns of individual employees. Workplace hours for Northern employers demonstrate a reasonable degree of variability.

Table 5 : Number of hours for which Northern workplaces are open

\begin{tabular}{lrr} 
Range of Hours & Frequency & Percentage \\
\hline Less than 7 & 5 & 0.4 \\
7 but less than 8 & 29 & 2.4 \\
8 but less than 9 & 267 & 22.1 \\
9 but less than 10 & 297 & 24.7 \\
10 but less than 12 & 266 & 22.2 \\
12 but less than 16 & 108 & 9.0 \\
16 but less than 20 & 51 & 4.2 \\
20 but less than 24 & 17 & 1.4 \\
24 & 161 & 13.4
\end{tabular}


The variability of workplace hours suggests that the median point is the most useful measure of central tendency. This falls at 10 hours across all respondents, but varies across industry, ranging from nine hours for Electricity, Gas and Water, Construction, Wholesale and Retail, Business and Financial Services and Central and Local Government, through to 12 hours for Transport and Storage and Community, Social and Personal Services.

Additional indicators of flexibility in the opening hours of Northern firms are provided by variance values, which were obtained on an industry basis. Variance measures the distribution of values around the mean, with a score of zero indicating no variance. Across all respondents, workplace hours showed considerable variance, with a score of 27.9. Differences were found on an industry basis, with the lowest scores being found for Construction (3.6) and Wholesale and Retail (6.2), and the highest values being obtained for Communications (40.7), Electricity, Gas and Water (46.9) and Community, Social and Personal Services (47.4). In addition, it is notable that 89 respondents $(6.7 \%)$ were unable to be classified into any category because of variations in their opening hours. Over three-quarters of these employers indicated that their workplace was open for a range of hours, depending on demand and the amount of work available.

The number of ordinary hours of work of full-time employees is subject to considerably less variability. In $68.3 \%$ of firms, employees worked between eight and nine hours, with only $17.9 \%$ working in excess of these hours. Again, a small group of respondents (8.8\%), were unable to be classified into any standard classification of hours because of variations in the standard number of hours worked by employees.

An industry breakdown of these figures demonstrates very little variance - the median and mode are eight hours for all industries except for Business and Financial Services where they are slightly lower at 7.5 hours. Variance values are less than 0.5 for all industries except Agriculture (0.5), Restaurants and Hotels (1.03) and Transport and Storage (1.77).

When asked whether they would seek to extend either their opening hours or the ordinary hours of employees over the next two years, it was found that the majority of respondents $(57 \%)$ did not seek any change in these areas. Only $23.6 \%$ sought to lengthen the number of hours for which workplaces were open, but a sizeable minority of $37 \%$ sought changes in the span of hours during which ordinary hours of work fall. These last two figures include $18.3 \%$ of respondents who sought to extend both workplace and employee hours.

Employer motivation for their decisions on working hours were largely related to demand, irrespective of whether they sought to change working hours or not. There were few industry differences in approaches taken to change in working time arrangements, but a clear pattern of responses related to size was found. Employers of less than ten staff were more likely than average to comment that they had no need to extend their hours, that they had sufficient flexibility already and that they preferred other alternatives, such as improving productivity, to extended hours. Employers of over 100 staff, on the other hand, were more than twice as likely to be seeking to extend daily hours of work, the days of the week worked, and to comment on the cost of overtime payments. This suggests that the closer personal relationships between employers and employees in small firms may result in fewer restrictions in employment practices, either because there is more "give-and-take" or alternatively because the parties are less likely to wish to disrupt the employment relationship by refusing requests for flexibility. 


\section{Qualitative flexibility}

Indicators of qualitative flexibility were considered in relation to the numbers of occupational classifications operating at each workplace, whether there were different grades within each classification, and any restrictions which prevented an employee from undertaking tasks normally undertaken by someone in another occupational classification.

Just over 55\% of employers had five or fewer occupational classifications operating in their workplaces, with an additional $33 \%$ having between six and ten. $70.6 \%$ of employers, however, reported employing different grades of staff in each classification. Only $25.7 \%$ of respondents indicated that there were restrictions within their workplaces which prevented employees from performing tasks normally undertaken by another classification. Almost exactly equal numbers of employers indicated that these restrictions originated from award definitions, union coverage, or traditional demarcations $(12.4 \%)$, as those that indicated that the restrictions were related to some skill or training requirement $(12.6 \%)$ ranging from general skills through to formal registration and licensing. Other reasons given were related to aptitude or personal factors $(4.3 \%)$ or attitudes $(1.4 \%)$. Increased size of firm was associated with more frequent reporting of restrictions of all kinds, but there was no significant variation across industry groups.

Some employers did not appear unhappy with the restrictions that were in place. Not all those who experienced restrictions anticipated changing their occupational classifications within the next two years, while others anticipated change for reasons unrelated to the restrictions that operated - such as the introduction of new technology.

Table 6 : Restrictions in occupational classifications and anticipated change by industry group.

\begin{tabular}{lcc} 
Industry & $\begin{array}{c}\text { \% reporting } \\
\text { restrictions }\end{array}$ & $\begin{array}{c}\text { \% anticipating } \\
\text { change }\end{array}$ \\
\hline All industries & 25.8 & 22.4 \\
Primary & 22.4 & 20.7 \\
Manufacturing & 30.1 & 31.7 \\
Electricity, Gas and Water & 36.4 & 27.3 \\
Construction & 25.5 & 21.4 \\
Wholesale and Retail & 10.7 & 12.5 \\
Restaurants and Hotels & 19.1 & 17.1 \\
Transport and Storage & 21.6 & 21.3 \\
Communications & 31.0 & 14.3 \\
Business and Finance & 21.7 & 9.9 \\
Social etc. Services & 39.4 & 21.7 \\
Central and Local Government & 60.0 & 35.0
\end{tabular}


Table 6 demonstrates industry differentials in the occupational restrictions that are reported by respondents. More detailed analysis of responses within industry groups, however, suggested that workplace size was the explanatory variable in relation to the operation of occupational restrictions. Thus the fact that some industry groups reported fewer or more restrictions than others was related to the tendency for firm size in that industry to be smaller or larger than average.

In relation to size, employers of over 50 employees were more likely than small ones to seek changes in occupational classifications. Smaller employers were more likely to comment that there was no need for change, that the classifications they operated were related to the nature of the business, and that they had sufficient flexibility already. A number of respondents specifically made the comment that it was in the nature of small business to be more flexible, and that they would not be able to operate unless all staff turned their hands to all types of work. Large employers on the other hand, were more than twice as likely as average to be seeking to move towards greater flexibility by such mechanisms as introducing multi-skilling, and moving towards the introduction of a site union or contract.

\section{Discussion}

The data presented above suggest four points in relation to the types of flexibility displayed by Northern firms, the extent to which there is pressure for change, and the sorts of additional flexibility sought in the future.

Firstly, it may be suggested that Northern workplaces enjoy a reasonably high degree of quantitative flexibility. This is demonstrated by the numbers of employers who made use of employment contracts other than the traditional full-time, permanent employee model. In comparison to data from other countries, the proportions found in this survey are relatively high, although direct comparisons are difficult to make because of differences in definition and survey design. Evidence from Britain, however, shows that only $18 \%$ of employers employed temporary employees, $19 \%$ made use of short, fixed-term contracts, $14 \%$ employed freelancers, and $4 \%$ employed homeworkers (Millward and Stevens, 1986). The more recent Australian Workplace Industrial Relations Survey (AWIRS), also suggests a significant degree of flexibility in workplace employment structures, with two thirds of workplaces employing part-time workers, and $25 \%$ making use of contractors, outworkers and agency workers (Callus et al., 1991). A variety of explanations for these inter-country differentials may be suggested to be worthy of further examination. These include the differences in survey timings, differing national regulatory environments, and differences in the extent and pace of change in New Zealand in comparison with the United Kingdom and Australia.

A slightly more ambiguous picture may be drawn in relation to qualitative flexibility. On the one hand, $55 \%$ of employers report fewer than five occupational classifications, and only a quarter reported the operation of restrictions in relation to these. On the other hand, over $70 \%$ of employers reported employing different grades of staff within classifications. This suggests a moderate degree of flexibility, with the constraints that do exist arising out of a paucity of skills and training opportunities rather than out of union or award requirements.

A second issue which may be noted from the data is that the pressure for greater 
flexibility in employment practices is not as urgent for Northern employers as some of the rhetoric would suggest. While about a third of employers wanted change in a range of areas, the rest appeared to be reasonably content to remain with the status quo. There are three potential explanations for this. Firstly, employers may in fact experience as much flexibility as they need at the current time, and therefore there may not be any need for them to seek change. This was suggested by those who commented that their working time and job flexibility arrangements gave them all the flexibility that they needed currently. Secondly, employers may experience rigidities, but may be content to operate within them for reasons of their own. This was suggested by those employers who, for example, did not want to extend the hours for which their business was open because of the effect on their own lifestyle. Thirdly, some employers suggested that despite exhortations about the need for change in order to cope with the changing economic environment, they and their employees preferred stability as a means of coping with uncertainty. As one respondent commented, "If one rocks the boat when the storm is raging, one must expect to sink", suggesting that for some employers the costs of change may in fact outweigh the benefits.

A third point, in considering the overall picture of the areas in which change is being sought, is that some types of flexibility are seen as being more desirable than others. This may be demonstrated by comparing response frequencies to a number of questions within the questionnaire.

Table 7 : Comparison of types of flexibility sought by respondents

\begin{tabular}{lcc} 
Type of flexibility & Frequency & Percentage \\
\hline Preference for additional employees to be part-time & 376 & 28.8 \\
Preference for additional employees to be temporary & 278 & 21.3 \\
Expectation of extending workplace hours & 305 & 23.5 \\
Expectation of extending ordinary hours of employees & 490 & 37.6 \\
Anticipate changing occupational classifications & 292 & 22.4
\end{tabular}

Thus, the area in which change is most frequently expected is in the area of working time arrangements. Fewer employers seek greater flexibility in their employment structures, but as has been noted this is an area in which employers already have a considerable degree of flexibility. In relation to occupational classifications, on the other hand, only a limited degree of flexibility is currently displayed, but there is little expectation that greater levels of flexibility will be achieved in the future. This suggests that high levels of quantitative rather than qualitative flexibility are seen as being desirable. A contrast may be made between this finding and recent Australian evidence which found that $86 \%$ of Australian workplaces had introduced at least one type of organisational change related to functional flexibility in the two years prior to the survey taking place (Green and MacDonald, 1991), suggesting that in that country the importance of greater qualitative flexibility is accorded a higher priority. 
A fourth point brought out by the data, however, is that the extent to which greater flexibility of different types is sought or expected varies amongst employers according to their size and the industry in which they operate. For example, employers expecting increased quantitative flexibility were more likely to be found in Electricity, Gas and Water, Construction, and Central and Local Government, and an expectation of greater qualitative flexibility was sought by Manufacturing employers. An even clearer association is found by analysing responses by size of firm however, with Table 8 demonstrating that larger employers are more likely than smaller ones to be expecting future change across a range of types of flexibility. The data suggest a number of variations according to firm size. Large firms were more likely to prefer to employ temporary employees, to seek to change working time arrangements and to report restrictions on the nature of work that could be performed by different occupational classifications. Small employers on the other hand were more likely across all areas of questioning to report that they already had the flexibility that they needed. This conclusion may be explained with reference to the greater degree of informality that generally applies to employment relationships in smaller firms, but also suggests that concerns about rigidities in working practices in New Zealand are more real for larger employers than they are for smaller ones. This finding is similar to that demonstrated by the AWIRS, which found that firms of over 500 employees had a greater propensity to introduce change than small and medium-sized ones (Green and MacDonald, 1991).

Table 8 : Comparison of types of flexibility sought by firm size

\begin{tabular}{llll}
$\begin{array}{l}\text { Size of } \\
\text { firm }\end{array}$ & $\begin{array}{l}\text { Preference } \\
\text { for additional } \\
\text { employees to be } \\
\text { temporary }\end{array}$ & $\begin{array}{l}\text { Expectation of } \\
\text { changing } \\
\text { ordinary hours } \\
\text { of work }\end{array}$ & $\begin{array}{l}\text { Anticipate } \\
\text { changes to } \\
\text { occupational } \\
\text { classification }\end{array}$ \\
\hline All size groups & 28.8 & 37.6 & 22.4 \\
$0-5$ & 22.4 & 23.1 & 9.3 \\
$6-9$ & 19.2 & 19.2 & 12.7 \\
$10-49$ & 27.1 & 35.5 & 16.7 \\
$50-99$ & 38.7 & 41.1 & 38.3 \\
$100-499$ & 35.9 & 52.8 & 38.8 \\
$500+$ & 46.0 & 82.0 & 62.0 \\
\hline
\end{tabular}

The above analysis leads to the question as to whether individual employers seek one type of flexibility at the expense of another type, or whether in fact they seek flexibility across a range of areas simultaneously. This question was answered by comparing the number of respondents who expected to change either workplace and/or employee hours with those who anticipated making changes to their occupational classifications. 
Table 9 : Comparison of quantitative versus qualitative flexibility

Frequency Percentage

Expect to change hours but not occupational classifications Expect to change occupational classifications but not hours Expect to change both Expect to change neither

307

113

179

691
23.8

8.8

13.9

53.6

Thus of the $46.4 \%$ of employers who sought change in one or other of these areas, about eighty percent expected to change their working time arrangements, while fewer than half anticipated changing their occupational classifications. This suggests that flexibility choices in Northern firms represent something of a trade off, and that quantitative flexibility is being sought at the expense of qualitative flexibility.

These findings may have serious implications for the long-term future of many New Zealand industries, particularly given the fact that production patterns of the future are more likely to require qualitative rather than quantitative flexibility. The constraints preventing employers from becoming more functionally flexible are related to skills and training, and there is little debate about the importance of these if New Zealand is to develop an up-to-date and competitive industry structure. At the same time New Zealand has a poor record in education participation rates, and in the implementation of technical and workplace-based training (Crocombe, Enright, and Porter, 1991). It is also noted that, despite the rhetoric of managers who say that their employees are their most important resource, this area of employee relations is one which often receives low priority in New Zealand firms. A recent study of how New Zealand firms have adjusted to the new deregulated environment, for example, found that of a range of improvements in management and operations implemented over the past five years, the lowest ratings were given to labour relations, staff training, and personnel policies (Harper and Malcolm, 1991). Thus, it is suggested that New Zealand employers have put a lower priority on the human resource issues which could contribute to solving problems related to longer-term adaptability of industry. Their ability to do so would appear to have been made possible through achieving short-term adaptation to a changing environment through quantitative flexibility.

\section{Conclusion}

Empirical studies of labour relations are not overly common in New Zealand, and the dangers of extrapolating from individual studies are well known. In particular, the data obtained by this survey suggests that the issue of workplace flexibility is not one which can be reduced to generalisations. Indications from Northern employers suggest that the ways in which firms use their employment patterns to assist in their adjustment to changing economic circumstances may vary across industries and different sizes of firm. There are some indications, however, that forms of flexibility which allow employers to adjust to short-term economic pressures are likely 
to be preferred over those which require employer investment in training and development and the active co-operation of the workforce. This is not to say that there are not employers in New Zealand who are taking a longer term strategic approach to human resource development and the management of their employees. It must be said, however, that this may be limited to larger and more sophisticated companies, and that smaller companies faced with the immediate pressures of survival in a harsh economic environment perceive themselves as being unable to afford the luxury of a strategic approach to the issue of labour relations and workplace flexibility.

\section{References}

Atkinson, J. and Meager, N. (1986), Changing Working Patterns: How Companies Achieve Flexibility to Meet New Needs, London, National Economic Development Office.

Baglioni, G. (1990), European Industrial Relations in the 1980s in Baglioni, G. and Crouch, C. (eds), European Industrial Relations: The Challenge of Flexibility, London, Sage Publications Ltd.

Bamber, G. (1990), Flexibility and Reform of Work Organisation - International Perspectives in Boxall, P. (Ed.), Function in Search of a Future, Auckland, Longman Paul.

Batstone, E. (1988), The Reform of Workplace Industrial Relations: Theory, Myth and Evidence, Oxford, Clarendon Press.

Birch, W. (1991), Address to the Longman Professional Conference on the Employment Contracts Act, Pan Pacific Hotel, Auckland, 7 May 1991.

Boyer, R. (1988), The Search for Labour Market Flexibility: The European Economies in Transition, Oxford, Clarendon Press.

Brosnan, P., Walsh, P., and Rowe, P. (1985), The Inactivities of Employer Unions, New Zealand Journal of Industrial Relations, 10(3): 141-156.

Brunhes, B. (1989), Labour Market Flexibility in Enterprises: A Comparison of Firms in Four European Countries in OECD, In Labour Market Flexibility: Trends in Enterprises, Paris, Organisation for Economic Cooperation and Development.

Callus, R., Morehead, A., Cully, M., and Buchanan, J. (1991), Industrial Relations at Work: The Australian Industrial Relations Workplace Survey, Canberra, Commonwealth Department of Industrial Relations. 
Crocombe, G., Enright, M., and Porter, M. (1991), Upgrading New Zealand's Competitive Advantage, Auckland, Oxford University Press.

Department of Statistics (1990), New Zealand Business Patterns 1990, Wellington, Department of Statistics.

Doeringer, P. and Piore, M. (1971), Internal Labour Markets and Manpower Analysis, Lexington, Massachusetts, Heath Lexington Books, D.C. Heath and Company.

Economic Monitoring Group (1986), Labour Market Flexibility, Wellington, New Zealand Planning Council.

Green, R. and MacDonald, D. (1991), The Australian Flexibility Paradox, Journal of Industrial Relations, 33(4): 564-585.

Hakim, C. (1990), Core and Periphery in Employers' Workforce Strategies: Evidence from the 1987 E.L.U.S. Survey, Work, Employment and Society, 4(2): 157-188.

Harper, D. and Malcolm, G. (1991), Surviving the Change: How Firms Adjusted to the New Environment, Research Monograph No 56, Wellington, New Zealand Institute of Economic Research.

Horstman, B. (1988), Labour Flexibility Strategies and Management Style, Journal of Industrial Relations, 30(3): 412-431.

Marginson, P. (1984), The Distinctive Effects of Plant and Company Size on Workplace Industrial Relations, British Journal of Industrial Relations, 22(1): 1-14.

Marginson, P., Edwards, P., Martin, R., Purcell, J., and Sisson, K. (1988), Beyond the Workplace: Managing Industrial Relations in the Multi-Establishment Enterprise, Oxford, Basil Blackwell Ltd.

McAndrew, I. (1989), Bargaining Structure and Bargaining Scope in New Zealand: the Climate of Employer Opinion, New Zealand Journal of Industrial Relations, 14(2): 133-148.

McAndrew, I. and Hursthouse, P. (1991), Reforming Labour Relations: What Southern Employers Say, New Zealand Journal of Industrial Relations, 16(1): 1-12.

Meulders, D. and Wilkin, L. (1987), Labour Market Flexibility: Critical Introduction to the Analysis of a Concept, Labour and Society, 12(1): 3-17.

Millward, N. and Stevens, M. (1986), British Workplace Industrial Relations 1980-1984, Aldershot, Gower Publishing Company Limited. 
OECD (1986a), Flexibility in the Labour Market: The Current Debate, Paris, Organisation for Economic Cooperation and Development.

OECD (1986b), Labour Market Flexibility: Report of a High-Level Group of Experts to the Secretary-General, Paris, Organisation for Economic Cooperation and Development.

OECD (1987), Structural Adjustment and Economic Performance, Paris, Organisation for Economic Cooperation and Development.

OECD (1989), Labour Market Flexibility: Trends in Enterprises, Paris, Organisation for Economic Cooperation and Development.

Owen, B. (1990), Organisation and Industrial Change at Nissan New Zealand in Boxall, P. (Ed.), Function in Search of a Future, Auckland, Longman Paul.

Pollert, A. (1987), The Flexible Firm: A Model in Search of Reality (or a policy in search of a practice)?, Warwick Papers in Industrial Relations No 19, Industrial Relations Research Unit, University of Warwick.

Pollert, A. (1988), The Flexible Firm: Fixation or Fact?, Work, Employment and Society, 2(3): 281-316.

Poole, M., Mansfield, R., Blyton, P., and Frost, P. (1982), Managerial Attitudes and Behaviour in Industrial Relations: Evidence from a National Survey, British Journal of Industrial Relations, 20(3): 285-307.

Purcell, J., and Sisson, K. (1983), Strategies and Practice in the Management of Industrial Relations, in Bain, G. (Ed.), Industrial Relations in Britain, Oxford, Basil Blackwell Ltd.

Sarfati, H., and Kobrin, C. (eds) (1988), Labour Market Flexibility: A Comparative Anthology, Geneva, International Labour Organisation.

Savage, J. (1989), Internal Labour Markets: Labour Adjustment Within Firms, Research Monograph No 45, Wellington, NZ Institute of Economic Research.

Taylor, A. G. (1991), Implications for Private Sector Bargaining: The View of a Large Employer, Address to Longman Professional Conference on the Employment Contracts Act, Pan Pacific Hotel, Auckland, 7 May 1991.

Williams, A., Owen, B., and Emerson, A. (1991), The Nissan Way: From Conflict to Commitment, Auckland, Williams Collins Publishers Ltd. 